\title{
A Mediating Role of Customer Value Between Customer Engagement and Loyalty: An Applied Study in Commercial Banks in Egypt
}

\author{
Eman Abdelhamid Hasnin ${ }^{1}$ \\ ${ }^{1}$ College of Economy and Administrative Science, Imam Mohamed bin Saud University, Riyadh, Saudi Arabia \\ Correspondence: Eman Abdelhamid Hasnin, College of Economy and Administrative Science, Imam Mohamed \\ bin Saud University, Riyadh, Saudi Arabia.
}

Received: January 3, 2018 Accepted: February 3, $2018 \quad$ Online Published: February 27, 2018

doi:10.5539/ijms.v10n1p136 URL: https://doi.org/10.5539/ijms.v10n1p136

\begin{abstract}
Purpose: The focus of this paper is providing a suggested approach to the nature of the relationship between the customer engagement and customer loyalty through the mediation role of the customer value.

Methodology/approach: Through its selection of commercial banks in Egypt and the use of statistical analysis method SPSS.11. The data was analyzed using the AMOS pathway analysis to identify the nature of the relationships between variables.

Findings: An artistic approach to understanding develop a model of the the relationship between customer value and customer loyalty within a mediating role of customer engagement in some commercial banks in Egypt. The research found that CE and CL improve the ability to building more effective customer service.
\end{abstract}

Keywords: customer engagement, loyalty, customer value, perceived value, mediating role, consumer research, banking marketing, marketing research

\section{Introduction}

The banking industry takes a huge part in the world economical knowledge. It is considered as a main part by the significant growth in the current years.

This growth should generate more interest in researching and analyzing the customer loyalty in order to face the global perspective.

In the last few years customer engagement has arisen as a subject of great importance to administrators and advisors in various businesses and corporations which was proven by the great amount of identifications, discussion forums, blogs, roundtables, explanations and conferences created by a general search for the terms.

\section{Customer Engagement}

$\mathrm{CE}$ is defined as "behaviors [that] go beyond transactions, and may be specifically defined as a customer's behavioral manifestations that have a brand or firm focus, beyond purchase, resulting from motivational drivers" (van Doorn et al., 2010, p. 254). It involves the customer interactive and brand experiences. It also enhances consumers' experienced brand value and is context-dependent (Brodie et al., 2011). CE is occasionally used to indicate the highest level of loyalty, but as behavioral exhibition, it covers all sorts of behaviors, not only behaviors that are distinctive of high levels of loyalty (Libai, 2011; Narayandas, 1998). Van Doorn et al. (2010) suggest that CE entails five dimensions. First, CE can be expressed in various ways that depend on the resources of the customer (e.g., time). Second, it can result in various types of results for the customer (e.g., improvements in the service). Thirdly, their capacity may vary and shorten, such as giving an objection or determining behavior. Fourth, it also has a changing impact on both the company and its partners. They work in behavior for various reasons. Customers engage in a number of behaviors that enhance their brand relationships beyond traditional customer loyalty standards such as repeat buying and buying behavior. Social media are the most common forms, referred to as "a group of Internet-based applications that build on the ideological and technological foundations of Web 2.0, and that allow the creation and exchange of User Generated Content" (Kaplan \& Haenlein, 2010 , p. 61). As of late, their potential has been underrated (Woisetschla ger et al., 2008), though social media platforms are considered best appropriate for developing relationships between customers (Kane et al., 2009). It is undeniably the ever-increasing role of social media that has formed a need for the idea of CE (Bielski, 2008). 
At the outset, a multitude of studies, each exploring a single fundamental component, marked research on engagement. Some articles focused on logical aspects as shown by Kilger \& Romer (2007), Malthouse \& Peck (2010), and Sprott et al. (2009). Others' focus was on sentimental aspects (Heath, 2009), while others focused on conative areas of engagement-represented by van Doorn et al. (2010) and Verhoef et al. (2010). For example, Van Doornet et al. (2010, p. 254) noted that commitment is behavioral in nature and suggested "CE goes beyond transactions, and is specifically defined as a customer's behavioral manifestation toward a brand or firm, beyond purchase, resulting from motivational drivers". As of late, writers started to explicate engagement using a more inclusive approach, offering abstract frameworks and an array of theories (Bowden, 2009; Brodie et al., 2011, 2013; Gambetti et al., 2012; Gummerus et al., 2012; Hollebeek, 2011, 2012). Most of these frameworks offer outlooks on how the components encircling the concept of engagement connect to each other. The authors stressed that the most useful engagement definitions are those that recognize the cognitive, emotional and behavioral dimensions of the concept.

\subsection{The Customer Engagement Cycle}

Based on the previous discussion, it is recommended that the focus of customer engagement centers on pleasing customers through giving greater value than that of the competitors in order to create long-term relationships based on trust and commitment where customers turn into partners within the sales team where they are added value and achieved better satisfaction from other customers and using social media in the process of building friendly bridges with customers full of trust among sellers. CE attracts customers by creating emotive words during their interactions with them. The progression of $\mathrm{CE}$ construction creates a $\mathrm{CE}$ cycle. The idea of a $\mathrm{CE}$ cycle has been formerly used in reference to consideration, inquiry, awareness, purchase as well as retention stages, which is shown in representing the stages in the purchase process which customers use to decide on which product to purchase, though with a reaction for future purchases, as opposed to CE as well as the first period novel consumer choosing the product to purchase. We suggest that the stages of the customer engagement cycle are connection, commitment, satisfaction, retention, interaction, advocacy, and engagement. Most of the difference in practitioner views on CE seems to stems from perplexing transitional stages in the CE cycle with $\mathrm{CE}$ itself. The $\mathrm{CE}$ cycle stages are discussed in the following:

\subsubsection{Connection}

These contacts are conducted using traditional methods such as personal sales and also using new digital methods via the Internet such as social media. Social media helps build relationships with customers and companies on a large scale. Existing contacts with customers can also be used as an important factor in building new connections with new customers and sellers. Sellers also contribute to the search for new customers and build effective communication with them. As one of the solutions proposed is to meet the needs of customers by offering new products. Sellers can create connections with possible customers prior to their need to be in a position that would suggest current products as solutions or even develop new products to meet those needs. Those connections are particularly important in transitional connections in business markets where needs of customers ensue from making products for customers in consequential transactions and a buying center with individuals from various departments and hierarchical levels of the organization arises to determine the product choices (Sashi, 2009).

\subsubsection{Interaction}

After they're connected, the customer can connect with seller employees like same customer. Prior to the internet, these connections were limited by existing technology such as, mobiles, word-of- mouth and meting to narrow circles of family, friends, acquaintances and colleagues restrained by location. But now, restrictions are disappearing quickly and metaphors such as global village is conjured to describe the real-time interactions among people throughout the world. Texting, instant messaging, blogging, email, virtual worlds and social networking are a few of the tools that allow for faster, more frequent, as well as better interactions between greater clusters of connected individuals, organizations and communities.

Interaction between vendors and customers is an essential element in value creation and creation. The Internet enables sellers to build continuous customer relationships, benefit from customer classifications, expand customer reach, and reach potential customers, where they can understand customer needs, In the process of developing new product. Customer interaction enables customers to contribute value addition and interaction with vendors to build customer value.

\subsubsection{Satisfaction}

Provided that the interactions of a seller and a customer or that between all community members, such as seller 
and customer satisfaction, they will stay linked as well as remain to cooperate with one another and achieve CE. satisfaction is not the goal in itself, seeing as the use of customer satisfaction surveys and rankings occasionally suggests a transitional footstep in strategies in order to reach the goal line of an organization. It has definitely been claimed that the goal line of marketing is not satisfaction in itself but the empowerment of the customer through partnerships with sellers that allow the customer communities to jointly establish their needs and desires. Customer satisfaction is an important condition for CE. Customer satisfaction and interaction during the procurement process can be followed by the purchase and the lack of satisfaction can disrupt the whole process and lead to the exit of the client at any time noting that satisfaction does not always lead to a repurchase .Thus, a long-term relationship may not occur. A difference has been made between transaction-specific and increasing customer satisfaction (Oliver, 1993), with increasing or complete satisfaction defined as "an overall evaluation based on the total purchase and consumption experience with a good or service over time" (Anderson et al., 1994). An increased satisfaction level could be reached when customer expectations are surpassed and when emotions become increasingly positive. This has been defined as not only a satisfaction but a joy as well.

\subsubsection{Retention}

Over time, customer retention occurs because of full satisfaction, positive feelings, and full satisfaction with the purchase. A long relationship between the seller and the customer though not essentially overly positive emotions for one another.

\subsection{Customer Engagement Value (CEV)}

Most of the previous researcher try to understanding CE using the consumer's perspective, and looking at the highest point of loyalty to the firm. As of late, more literature has discovered the business side of $\mathrm{CE}$ and customer lifetime value, pushing a much bigger heaviness on the value that $\mathrm{CE}$ produces for service firms and its significance to consultants. Kumar et al. (2010) examine the added value to the service firm from CE behavior and classify three types of customer engagement value (CEV): Frist Customer lifetime value (CLV) also known as customer purchasing behavior is defined as "the present value of future profits generated from a customer over his or her life of business with the firm". CLV is the transactional aspect of engagement that comprises the regularity of purchasing, amount purchased, and so on. Seeing as CLV emphases on the exchange transaction, it becomes the key orientation point. When service firms estimate both long-term and short-term engagement strategies. Second Customer referral value (CRV) accumulates from customers' referrals of new customers as a result to firm-initiated and -incentivized referral programs. Referrals are vital in the sense that they have the ability to decrease the cost of the purchase for the firm and bring in future income. Given the growth of the internet and social media sites like Facebook and Twitter, CRV becomes an essential aspect of CE. CRV is focused entirely on current customers changing forecasts in their social network (both online and offline) into actual customers for which they are satisfied. In many ways these referring customers are like non-employee salespeople, receiving a command from the sale and can be a real way of transporting in new customers. Third Customer influencer value (CIV) increases from the influence of customer on other customers as well as forecasts by considerable and translating prospects to customers as inspirational other customers to increase their share of wallet with the firm, creating a shared service experience and assisting other customers in service usage.

\section{Customer Value}

Many studies have linked the perceived value of clients to loyalty, both directly and indirectly. The most important of these studies (Chiou 2004; Hellier et al., 2003). Strategy is in the hands of the organization to create a competitive advantage and achieve long-term success. According to Parasuraman \& Grewal (2000), there are four types of value: acquisition value, transaction value, value of use, and value of consumption. The value concept of organizations in the past has been closely linked to price and quality, but a number of studies have indicated that the perceived value of customers has social, emotional and psychological dimensions, as well as the time, money and effort to obtain a specific product or service (Huber et al., 2001). Both Lin \& Wang (2006) believe that the value may be internal, such as how does the customer feel after purchasing? Or could be external such as the reputation of the product used and its image. One of the most prominent definitions of the concept of perceived value for customers in marketing literature was Zeithaml (1988, p. 14), where the perceived value of customers was defined as "the general assessment of customers in relation to the benefit obtained from a specific product, mainly based on their perceptions of what they received in exchange for what they gave."

H.1 There are no statistically significant relationship between customer engagement in terms of dimensions and customer value. 


\section{Customer Loyalty}

Customer loyalty has been defined as "a person's tendency to persist over time in showing a similar trend in positions similar to those he has encountered in the past".

Increased interest in brand loyalty has emerged in marketing research in recent years because loyal customers are more likely to repeat purchases from a particular organization, or to increase their share of purchases from a particular supplier. These clients may be involved in promoting the organization by recommending them to their friends (Cengize \& Reicheeld, 2007).

H.2 There are no statistically significant relationship between customer engagement and customer loyalty.

H.3 There are no statistically significant relationship between customer value and customer loyalty.

\section{The Relationship between $\mathrm{CE}$ and Loyalty}

The CE can be seen as a consecutive process of people passing through to achieve loyalty to a particular product or brand. This psychological process can not only create loyalty to new customers but maintain the loyalty of existing customers and repeat their purchases (Bowden, 2009). The process of customer engagement involves a cumulative and calculated commitment to the customer and is largely the cognitive basis of the purchase. As the levels of participation supported by increasing levels of confidence and buying frequency develop, the relationship develops and reaches an emotional commitment to the mark (Puqing, 2014; Gupta, 2012).

H.4 There are no Statistically significant relationship between CE and loyalty through customer value.

\section{Problem Statement}

This study doing exploratory studied to develop a model of the the relationship between customer value and customer loyalty within a mediating role of customer engagement in some commercial banks in Egypt. Based upon the formulation of research problem: What is the kind of relationship between the value of the customer and customer loyalty What is the impact of customer engagement as mediator between the value of customers and customer loyalty?

\section{Research Objectives}

The Egyptian commercial banks sector is observing a strong competition. Therefore, these sectors try to establish relationships with their customers to avoid them from turning to other providers. To this goal, several Egyptian commercial banks have begun introducing more value to their customers. The main aim of this research is to: 1) Evaluate the customer engagement practices within the context of customer value. 2) Determine the relationship of $\mathrm{CV}$ and $\mathrm{CL}$ within $\mathrm{CE}$.

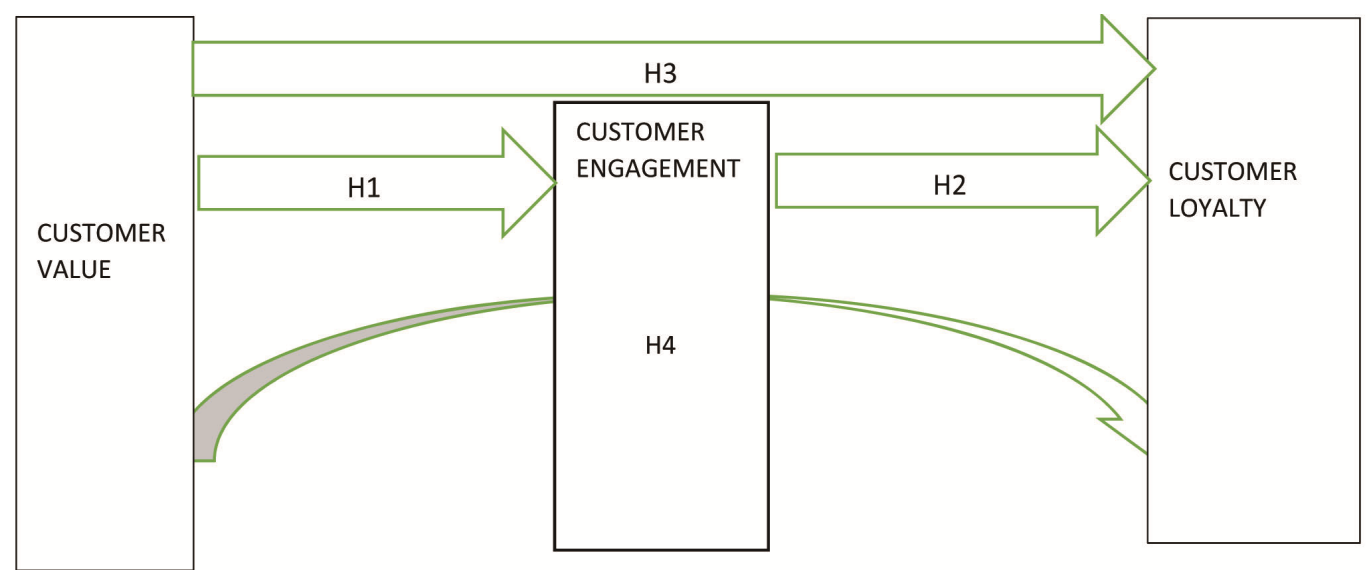

Finger 1. The conceptual model of the study

\section{Sample Characteristic}

The paper assumes that the number of customers who are frequented by the commercial banks within a certain period of time are more than 100000 customer and then will be taking a sample of hesitant of 384 individual, with a boundary of error of 5\% and sureness factor $95 \%$ and availability of characteristics required to be studied in the community $50 \%$.According to the financial reports of the commercial banks at the end of 2014, we notes 
that the volume of customer deposits in public banks is twice as high as the deposits of customers of private banks. Accordingly, the sample was distributed by 2: 1, number 256 customers were taken from public banks with 64 individuals from each bank or 32 individuals from each branch. One of the customers of the private banks with 32 individuals per bank, 16 items per branch. It was noticed that the customer survey statements were distributed in the same branches chosen for conducting the field study. The statements were filled in with the personal interview and the response rate was $99.7 \%$.

\section{Questionnaire and Variables Development Procedures}

The questionnaire measuring device used to investigate the role of customer value as mediator between customer engagement and Loyalty. After reviewing of theoretical farm, the researcher suggested the use of multi- scales. And modify reliable and valid scales for each variable and use SPSS version 20 fo statistical analysis purpose.

The survey gadget used in this study included four established scales. The measure of customer engagement was improved from Aiste Dovaliene et al. (2015) and Matti et al. (2011). Customer engagement variables include:

Frist, Communication: The existence of links between the bank and the client, The enthusiasm to communicate with the bank, Feeling of partnership with the bank. Second, Interaction: The Bank's interest in discussing the advantages of the services it provides with the client, The interest of the bank to study the ideas and proposals provided by the client. Third, satisfaction: Delivering service beyond customer expectations, Customer Satisfaction, Sufficiency of the bank and lack of attention to competitors.

Fourth, Retention: Competitive prices, Continuous personal contacts with the client, Intentions continue to be treated as a result of the experience curve.

Fifth, Commitment: Customer confidence, Customer trust in service offerings.

Sixth, Support, Recommending dealing with the bank, word of mouth. Then customer value was adapted from Velitchka et al. (2014), Aiste et al. (2015).

Finally, Customer value include: The Bank's ability to understand customer needs, Extent of branches and ATMs, The utility is spatial and temporal, Technology used in service delivery, price and fairness, Rate of return on bank deposits, Eligibility in the bank's policies. At the final loyalty was adapted from Ingrid M. O'Brien et al. (2015). It includes: Intentions to re-deal, Pay annual profits, Word of mouth, Commitment towards the bank, Bank customer's preferences, Demand for banking services, Contin Competitive uous visits to the bank, Relations with employees, Not paying attention to competition offers, The bank is the first choice.

\section{Hypotheses Testing and Discussion}

As results of correlations matrix exhibitions, a significant relationship between the variables were predictable path. CL was positively related to CV sub-dimensions, and negatively to $\mathrm{CE}$,

Table 1. Correlation coefficient between CE, CV, CL

\begin{tabular}{lllll}
\hline$S$ & factors & $\underline{\mathbf{1}}$ & $\underline{\mathbf{2}}$ & $\underline{\mathbf{3}}$ \\
\hline 1 & Customer engagement & .88 & & \\
2 & Customer value & .72 & .62 & \\
3 & Customer loyalty & .67 & .81 & .77 \\
\hline
\end{tabular}

Table 2. Fit indices of operational equation models

\begin{tabular}{llllllll}
\hline$X 2$ & $D F / x 2$ & $G F I$ & $R M S E A$ & NFI & CFI & TLI & IFI \\
\hline 4.44 & .053 & 0.87 & .04 & .91 & .95 & .97 & .93 \\
\hline
\end{tabular}

Table 2 displays the goodness-of-fit to the model proposed, significant $(\mathrm{p}<0.05)$, also represents that the ratio between $\mathrm{df} / \mathrm{x} 2$ is less than2; it means fits of data in additions the values of RMSEA less than 00.05 represent that adequate fit. Thus GFI is high and trends to 1, also is signifies that the model of study fitting with sample data, finally, NFI,CFI.TLI and IFI for all values are greater than .90 , it means a good fit.

As shows in table 3 , There are a positive relationship between $\mathrm{CE}$ and $\mathrm{CL}$ where estimations of standardize regression weights 0.36 and $p<0.01$, this represents that $\mathrm{CE}$ has an obviously positive influence on CL. As well as, H1. is supported. The result represents a positive relationship between $\mathrm{CE}$ and $\mathrm{CV}$ where estimations of standardize regression weights 0.23 and $\mathrm{p}<0.01$, this represents that $\mathrm{CE}$ has an obviously positive influence on $\mathrm{CV}$. As well as, H2. is supported. 
At last there is a positive relationship between CV and CL where estimations of standardize regression weights 0.18 and $\mathrm{p}<0.01$, this represents that $\mathrm{CV}$ has an obviously positive influence on CL. As well as, H3. is supported

Table 3. Identical regression weightiness of model variables

\begin{tabular}{llll}
\hline Hypothesis & Reg. coff. & T-test & Sig. \\
\hline $\mathrm{H} 1 . \mathrm{CE} \longrightarrow \mathrm{CL}$ & 0.36 & 11.45 & 0.000 \\
$\mathrm{H} 2 . \mathrm{CE} \longrightarrow \mathrm{CV}$ & .023 & 6.22 & 0.000 \\
$\mathrm{H} 3 . \mathrm{CV} \rightarrow \mathrm{CL}$ & 0.18 & 5.81 & 0.000 \\
$\mathrm{H} 4 . \mathrm{CE} \rightarrow \mathrm{CV} \rightarrow \mathrm{CL}$ & 0.51 & 3.77 & 0.000 \\
\hline
\end{tabular}

Table 4 shows the total effect of direct and indirect effects- of CE on customer loyalty is .0812 is significant, However, indirect effect is larger and significant (0.49) than direct effect $(0.322)$. These results imply that CE acts as a mediator between CV and CL. Thus, H4 supported.

Table 4. Direct and indirect effect of CL

\begin{tabular}{llllllll}
\hline path & & Direct effect & Sig. & Indirect effect & Sig. & Total effect & Sig. \\
$\mathrm{CE} \longrightarrow \mathrm{CV}$ & .86 & 0.000 & & & .86 & 0.000 \\
$\mathrm{CE} \longrightarrow \mathrm{CL}$ & .49 & 0.000 & 0.322 & 0.000 & .812 & 0.000 \\
$\mathrm{CV} \longrightarrow \mathrm{CL}$ & .67 & 0.000 & & & .67 & 0.000 \\
$\mathrm{CE} \rightarrow \mathrm{CV}$ & $\longrightarrow \mathrm{CL}$ & .23 & 0.000 & 0.220 & 0.000 & .45 & 0.000 \\
\hline
\end{tabular}

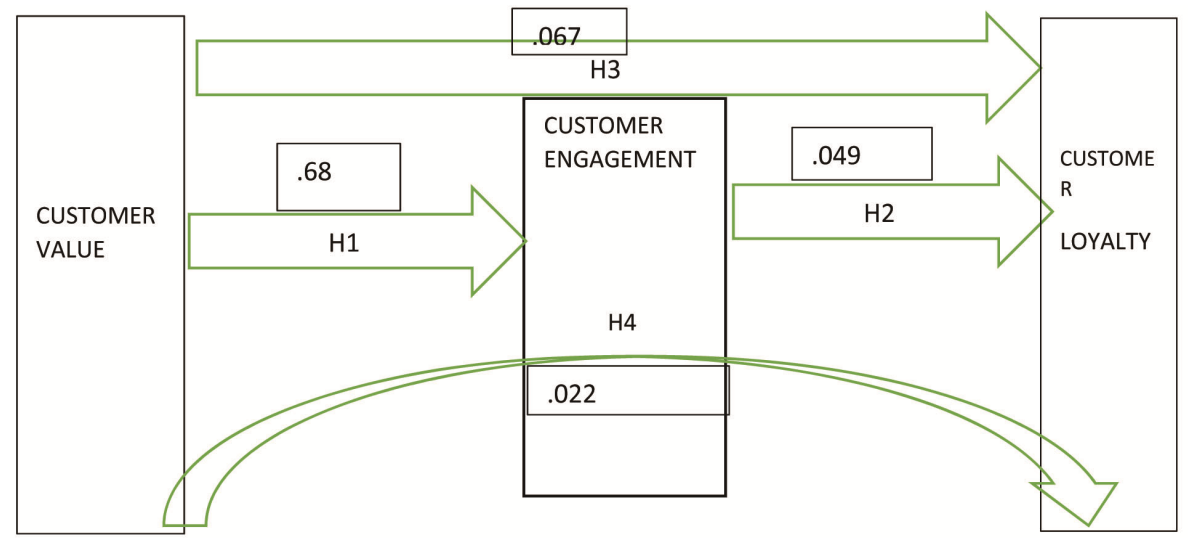

Finger 2. The final conceptual model of the study

\section{Conclusion}

The accrued benefits of this research found that CE and CL improve the ability to building more effective customer service. The Banks must be conscious of the significant role of CV to increasing CL through applying $\mathrm{CE}$ role. The banks concerned should be interested in improving the customer relationship, studying their proposals, and taking care to implement the concepts of customer engagement as well as the life cycle of customer engagement.

The banks must seek to approach the customer orientation rather than the market orientation to reach customer loyalty, considering that the customer is the origin of any activity. Also should realize that customer loyalty is highly correlated with the best expected value and can be achieved through customer engagement. The customer's reaction to the bank's compliance with the bank will turn into positive trends towards the bank because of obtaining added value in the direction of loyalty to the bank.

\section{Research Limitation}

This study own characterizes and borders that should be declared. First, results may partial by common method communal method adjustment because surveys were used to measure CE, CV, CL. It may be related with varies factors like customer expectations and CRM. Second, this study applied on commercial banks, outcomes may be differenced when request filed are changed (e.g., telecommunication, on line marketing, etc.). Thus, it is 
therefore wrong to generalize the results to other organizations.

Finally, this paper examined the role of CE on CL without exposure to the impact of CE sub-dimensions like connection, retention and, thus, upcoming research requests to survey it.

\section{Future Research Scope}

The subject of customer engagement is a fertile area for future studies due to the novelty of this subject. Therefore, we suggest the following:

Community research: The application can be extended in other fields such as telecommunications, hotels, universities, travel companies ...

Search Variables: Other variables can be introduce in the customer relationship management, such as trust, introspection and participation, can be considered.

The level of analysis: The analysis can be conducted at the level of each bank separately and then can be compared between public and private commercial banks.

\section{References}

Ahluwalia, R., Burnkrant, R. E., \& Unnava, H. R. (2000). Consumer response to negative publicity: the moderating role of commitment. Journal of Marketing Research, 37(2), 203-214. https://doi.org/10.1509/jmkr.37.2.203.18734

Aiste, D., Akvile, M., \& Zaneta, P. (2015). The relations between customer engagement, perceived value and satisfaction: the case of mobile applications. 10th International Scientific Conference Economics and Management. University of Technology. http://dx.doi.org/10.5755/j01.ee.27.2.14030

Anderson, E. W., Fornell, C., \& Lehmann, D. R. (1994). Customer satisfaction, market share, and profitability: findings from Sweden. Journal of Marketing, 58, 53-66. https://doi.org/10.2307/1252310

Auger, P., Devinney, T., \& Louviere, J. (2007). Using best-worst scaling methodology to investigate consumer ethical beliefs across countries. Journal of Business Ethics, 70(3), 299-326. https://doi.org/10.1007/s10551-006-9112-7

Bejtagic-Makic, M., \& Duman, T. (2013). Key Motivational Drivers for Customer Engagement on Facebook Brand Fan Pages in Bosnia \& Herzegovina. International Conference on Economic and Social Studies.

Bowden, J. L. H. (2009). The process of customer engagement: a conceptual framework. Journal of Marketing Theory \& Practice, 17(1), 63-74. http://dx.doi.org/10.2753/MTP1069-6679170105

Brodie, R. J., Ilic, A., Juric, B., \& Hollebeek, L. (2013). Consumer engagement in a virtual brand community: an exploratory analysis. Journal of Business Research, 66(1), 105-114. http://dx.doi.org/10.1016/j.jbusres.2011.07.029

Cambra-Fierro, J., Melero-Polo, I., \& Vazquez-Carrasco, R. J. (2013). Customer engagement: Innovation in nontechnical marketing processes. Innovation: Management, Policy \& Practice, 15(3). https://doi.org/10.5172/impp.2013.15.3.326

Dong, B., Evans, K. R., \& Zou, S. (2008). The effects of customer participation in co-created service recovery. Journal of the Academy of Marketing Science, 36, 123-137. https://doi.org/10.1007/s11747-007-0059-8

Doom, J. V., Lemon, K. N., \& Mittal, V. (2010). Customer Engagement Behavior: Theoretical Foundations and Research Directions. Journal of Service Research, 13(3).

Dutot, V. (2013). A New Strategy for Customer Engagement: How Do French Firms Use Social CRM? International Business Research, 6(9). http://dx.doi.org/10.5539/ibr.v6n9p54

Endacott, R. W. J. (2004). Consumers and CRM: a national and global perspective. Journal of Consumer Marketing, 21(3), 183-189. https://doi.org/10.1108/07363760410534731

Fehrar, J., Woratschek, H., \& Germelmann. (2013). Christian Antecedents and Consequences of Customer Engagement, A literature review. ANZMAC Conference Proceedings.

Flynn, L. M. (2012). An Exploration of Engagement: A Customer Perspective. Ph.d. Dissertation, DePaul University, Chicago, Illinois.

Gallup Consulting. (2010). Customer engagement: the customer side of the Human Sigma Equation. Retrieved from http://eu.gallup.com/Consulting/118180/Customer-Engagement.aspx

Gallup, C. (2009). Customer engagement: what's your engagement ratio? Retrieved from 
www.gallup.com/consulting/File/121901/Customer_Engagement_Overview_Brochure.pdf

Gambetti, R. C., \& Graffigna, G. (2010). The concept of engagement. International Journal of Market Research, 52(6), 801-826. https://doi.org/10.2501/S147078531020166

Gambetti, R. C., Graffigna, G., \& Biraghi, S. (2012). The grounded theory approach to consumer-brand engagement: the practitioner's standpoint. International Journal of Market Research, 54(5), 659-687. https://doi.org/10.2501/IJMR-54-5-659-687

Gummerus, J., Liljander, V., Weman, E., \& Pihlstrom, M. (2012). Customer engagement in a Facebook brand Community. Management Research Review, 35(9), 857-877. https://doi.org/10.1108/01409171211256578

Hadcroft, P., \& Jarratt, D. (2007). Market orientation: an iterative process of customer and market engagement. Journal of Business-to-Business Marketing, 14(3). https://doi.org/10.1300/J033v14n03_02

Hanssen, K. J., \& Faegri, T. E. (2006). Agile customer engagement: a longitudinal qualitativecase study. Proceedings of the 2006 ACM/IEEE International Symposium on Empirical Software Engineering in Rio de Janeiro, pp. 164-173. https://doi.org/10.1145/1159733.1159759

Hasnin, E. A. (2017). The Impact of Entrepreneurial Marketing Behavior on Customer Relationship Management: An Applied Study on Mobile Phone Customers in Egypt. Journal of Marketing and Consumer Research, 41, 80-89.

Higgins, E. T., \& Scholer, A. A. (2009). Engaging the consumer: the science and art of the value creation process. Journal of Consumer Psychology, 19(2), 100-114. https://doi.org/10.1016/j.jcps.2009.02.002

Hollebeek, L. (2011). Exploring customer brand engagement: definition and themes. Journal of Strategic Marketing, 19(7), 555-573. https://doi.org/10.1080/0965254X.2011.599493

Hollebeek, L. D. (2011). Demystifying customer brand engagement: Exploring the loyalty nexus. Journal of Marketing Management, 27, 785-807. https://doi.org/10.1080/0267257X.2010.500132

Hollebeek, L. D. (2012). The customer engagement/value interface: an exploratory investigation. Australasian Marketing Journal, 21(1), 17-24. http://dx.doi.org/10.1016/j.ausmj.2012.08.006

Hou, J., Du, L., \& Li, J. (2008). Cause's attributes influencing consumer's purchasing intention: empirical evidence from China. Asia Pacific Journal of Marketing and Logistics, 20(4), 363-380. https://doi.org/10.1108/13555850810909704

Jaakkola, E., \& Alexander, M. (2014). The role of customer engagement behavior in value co-creation a service system perspective. Journal of Service Research, 17(3). https://doi.org/10.1177/1094670514529187

Kaltcheva, V. D., \& Parasuraman, A. (2009). Personality relatedness and reciprocity framework for analyzing retailer consumer interactions. Journal of Business Research, 62(6), 601-608. http://dx.doi.org/10.1016/j.jbusres.2008.05.019

Kaltcheva, V. D., Winsor, R. D., \& Parasuraman, A. (2010). The impact of customers' relational models on price-based defection. Journal of Marketing Theory and Practice, 18(1), 5-22. http://dx.doi.org/10.2753/MTP1069-6679180101

Kilger, M., \& Romer, E. (2007). Do measures of media engagement correlate with product purchase likelihood?. Journal of Advertising Research, 47(3), 313-325. https://doi.org/10.2501/S002184990707033X

Kumar, V., Aksoy, L., Donkers, B., Venkatesan, R., Wiesel, T., \& Tillmanns, S. (2010). Undervalued or overvalued customers: capturing total customer engagement value. Journal of Service Research, 13(3), 297-310. http://dx.doi.org/10.1177/1094670510375602

Lee, J. A., Soutar, G. N., \& Louviere, J. (2007). Measuring values using best-worst scaling: the LOV example. Psychology \& Marketing, 24(12), 1043-1058. https://doi.org/10.1002/mar.20197

Lee, J. A., Soutar, G., \& Louviere, J. (2008). The best-worst scaling approach: an alternative to Schwartz's

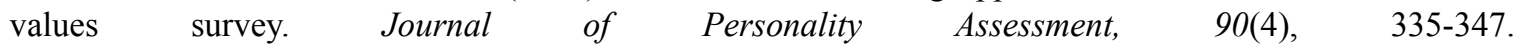
https://doi.org/10.1080/00223890802107925

Matti, H., Earl, R. B., \& Earl, R, N. (2011). The drivers of customer satisfaction in strategic consulting engagements A global study. Management Decision, 49(8). https://doi.org/10.1108/00251741111163160

McMullan, R. (2005). A multiple-item scale for measuring customer loyalty development. Journal of Services Marketing, 19(7), 470-481. https://doi.org/10.1108/08876040510625972 
Mollen, A., \& Wilson, H. (2010). Engagement, telepresence and interactivity in online consumer experience: Reconciling scholastic and managerial perspectives. Journal of Business Research, 63, 919-925. http://dx.doi.org/10.1016/j.jbusres.2009.05.014

Morais, D. B. (2000). Reconceptualization of Loyalty under a Resource Investment Perspective: A Study of Group Leaders in the Leisure Service Industry. Unpublished Ph.D. Dissertation, Clemson University. Retrieved from http://scholarworks.umass.edu/ttra/2007/Presented_Papers/59

Petrick, J. F. (2002). Development of a multi-dimensional scale for measuring the perceived value of a service. Journal of Leisure Research, 34, 119-134. doi/abs/10.1080/00222216.2002.11949965

Porter, C. E., Donthu, N., MacElroy, W. H., \& Wydra, D. (2011). How to foster and sustain engagement in virtual communities. California Management Review, 53(4), 80-110. https://doi.org/10.1525/cmr.2011.53.4.80

Roberts, C., \& Alpert, F. (2010). Total customer engagement: designing and aligning key strategic elements to achieve growth. Journal of Product \& Brand Management, 19(3), 198-209. https://doi.org/10.1108/10610421011046175

Salanova, M., Agut, S., \& Peiro, J. M. (2005). Linking organizational resources and work engagement to employee performance and customer loyalty: the mediation of service climate. Journal of Applied Psychology, 90(6), 1217-1227. https://doi.org/10.1037/0021-9010.90.6.1217

Smith, J. B., \& Colgate, M. (2007). Customer value creation: a practical framework. Journal of Marketing Theory and Practice, 15, 7-23. https://doi.org/10.2753/MTP1069-6679150101

Sterling, G. (2014). Report: Mobile Users Spend 80 Percent Of Time In Just Five Apps. (Interactive). Retrieved from http://marketingland.com/report-mobile-users-spend-80-percent-time-just-five-apps-116858

Van Doorn, J., Lemon, K. N., Mittal, V., Nass, S., Pick, D., Pirner, P., \& Verhoef, P. C. (2010). Customer engagement behavior: Theoretical foundations and research directions. Journal of Service Research, 13, 253-266. https://doi.org/10.1177/1094670510375599

Velitchka, D. K. et al. (2014). Customers' relational models as determinants of customer engagement value. Journal of Product \& Brand Management, 23(1). https://doi.org/10.1108/JPBM-07-2013-0353

Wang, H. Y., Liao, C., \& Yang, L. H. (2013). What affects mobile application use? The roles of consumption values. International Journal of Marketing Studies, 5(11). http://dx.doi.org/10.5539/ijms.v5n2p11

Wang, Y., Po Lo, H., Chi, R., \& Yang, Y. (2004). An integrated framework for customer value and customer-relationship-management performance: a customer-based perspective from China. Managing Service Quality: An International Journal, 14, 169-182. https://doi.org/10.1108/09604520410528590

Yavas, U., Birkenstein, M., \& Stuhldreier, U. (2004). Relationships between service quality and behavioral outcomes A study of private bank customers in Germany. The International Journal of Bank Marketing, 22(2), 144-157. https://doi.org/10.1108/02652320410521737

\section{Copyrights}

Copyright for this article is retained by the author, with first publication rights granted to the journal.

This is an open-access article distributed under the terms and conditions of the Creative Commons Attribution license (http://creativecommons.org/licenses/by/4.0/). 